\title{
Synthesis, Structure, and Sodium Mobility of Sodium Vanadium Nitridophosphate: A Zero-Strain and Safe High Voltage Cathode Material for Sodium-Ion Batteries
}

\author{
Huang Zhang ${ }^{1,2}$ (D), Daniel Buchholz ${ }^{1,2, *}$ and Stefano Passerini ${ }^{1,2, *}$ \\ 1 Helmholtz Institute Ulm, Helmholtzstraße 11, 89081 Ulm, Germany; huang.zhang@kit.edu \\ 2 Karlsruhe Institute of Technology (KIT), P.O. Box 3640, 76021 Karlsruhe, Germany \\ * Correspondence: daniel.buchholz@kit.edu (D.B.); stefano.passerini@kit.edu (S.P.); \\ Tel.: +49-731-503-4101 (D.B. \& S.P.)
}

Received: 6 June 2017; Accepted: 28 June 2017; Published: 30 June 2017

\begin{abstract}
Herein, the nitridophosphate $\mathrm{Na}_{3} \mathrm{~V}\left(\mathrm{PO}_{3}\right)_{3} \mathrm{~N}$ is synthesized by solid state method. $X$-ray diffraction (XRD) and Rietveld refinement confirm the cubic symmetry with $P 2{ }_{1} 3$ space group. The material exhibits very good thermal stability and high operating voltage of $4.0 \mathrm{~V} \mathrm{vs}$. $\mathrm{Na} / \mathrm{Na}^{+}$ due to $\mathrm{V}^{3+} / \mathrm{V}^{4+}$ redox couple. In situ X-ray diffraction studies confirm the two-phase (de-)sodiation process to occur with very low volume changes. The refinement of the sodium occupancies reveal the low accessibility of sodium cations in the $\mathrm{Na} 2$ and $\mathrm{Na} 3$ sites as the main origin for the lower experimental capacity $\left(0.38\right.$ eq. $\left.\mathrm{Na}^{+}, 28 \mathrm{mAh} \mathrm{g}^{-1}\right)$ versus the theoretical one (1.0 eq. $\left.\mathrm{Na}^{+}, 74 \mathrm{mAh} \mathrm{g}^{-1}\right)$. These observations provide valuable information for the further optimization of this materials class in order to access their theoretical electrochemical performance as a potentially interesting zero-strain and safe high-voltage cathode material for sodium-ion batteries.
\end{abstract}

Keywords: sodium-ion battery; cathode; $\mathrm{Na}_{3} \mathrm{~V}\left(\mathrm{PO}_{3}\right)_{3} \mathrm{~N}$; high voltage; safety

\section{Introduction}

The growing demand for sustainable energy leads to an increasing interest in efficient energy storage systems (EES). Among these, lithium-ion batteries (LIBs) have received strong scientific attention and, indeed, have undergone rapid development since their commercialization in 1991 [1]. However, the fact of continued lithium resource consumption and its limited abundance in earth's crust has driven people to renew their interest in beyond-lithium chemistries [2]. Sodium ion batteries (NIBs) have, therefore, been reconsidered as promising alternatives due to the low cost and high abundance of Na resource, and good electrochemical performance [3,4]. The main challenge associated with these systems is to optimize energy density, rate capability, and sustainability of the active materials $[5,6]$. Since the energy of a battery is largely dependent on the gravimetric and volumetric capacities and operating voltages of the electrode materials, exploration on suitable active materials is highly-targeted.

In this pursuit, there have been intensive efforts on expanding the range of available structural families. One strategy is to develop Na-containing host materials from lithium analogues. Such efforts have resulted in tremendous successes in realizing some known polyanionic frameworks, such as phosphate $\mathrm{NaMPO}_{4} / \mathrm{Na}_{3} \mathrm{M}_{2}\left(\mathrm{PO}_{4}\right)_{3}$ [7,8], pyrophosphate $\mathrm{Na}_{2} \mathrm{MP}_{2} \mathrm{O}_{7}$ [9], fluorophosphate $\mathrm{NaMPO}_{4} \mathrm{~F} / \mathrm{Na}_{3} \mathrm{M}_{2}\left(\mathrm{PO}_{4}\right)_{2} \mathrm{~F}_{3}$ [10,11], sulfate $\mathrm{Na}_{x} \mathrm{M}\left(\mathrm{SO}_{4}\right)_{2}$ [12], fluorosulfate $\mathrm{NaMSO}_{4} \mathrm{~F}$ [13], silicate $\mathrm{Na}_{2} \mathrm{M}\left(\mathrm{SiO}_{4}\right)$ [14], and mixed polyanionic $\mathrm{Na}_{4} \mathrm{M}_{3}\left(\mathrm{PO}_{4}\right)_{2}\left(\mathrm{P}_{2} \mathrm{O}_{7}\right)[15,16]$ compounds (where $\mathrm{M}$ represents the transition metal ion). Basically, the electrochemical properties of anticipated polyanion electrode materials, including the operating potential and specific capacity, rely on the $\mathrm{Mn}^{+} / \mathrm{M}^{(\mathrm{n}+\mathrm{x})+}$ redox 
process and the natures of polyanionic frameworks, i.e., electronegativity and molecular weight [17]. Among these reported polyanion cathodes, the NASICON-type $\mathrm{Na}_{3} \mathrm{~V}_{2}\left(\mathrm{PO}_{4}\right)_{3}$ in a rhombohedral structure with the space group R-3c attracts particular interest due to the vanadium redox couple, enabling a relatively high working voltage of $\sim 3.4 \mathrm{~V}$ (vs. $\mathrm{Na}^{+} / \mathrm{Na}$ ), and the framework of $\mathrm{PO}_{4}$, enabling superior thermal stability $[8,18]$. During the course of the investigation of the vanadium-based phosphate family, it was found that doping with the more electronegative fluoride can enhance the operating potential of electroactive materials. For example, the $\mathrm{Na}_{3} \mathrm{~V}_{2}\left(\mathrm{PO}_{4}\right)_{2} \mathrm{~F}_{3}$ compound shows promising potential improvement due to the high electronegativity of $\mathrm{F}$ ions $[19,20]$.

Of particular interest are the members of a new compounds class with general formula $\mathrm{A}_{2}{ }_{2} \mathrm{M}^{\mathrm{II}}{ }_{2}\left(\mathrm{PO}_{3}\right)_{3} \mathrm{~N}$, where $\mathrm{A}=\mathrm{Na}$ or $\mathrm{Li}, \mathrm{M}=\mathrm{Mg}, \mathrm{Fe}, \mathrm{Mn}$, and $\mathrm{Co}$, which are addressed as potential electrode materials for lithium ion batteries. In fact, the polyanionic structure with $\mathrm{N}^{3-}$, arising from three $\mathrm{PO}_{3} \mathrm{~N}$ tetrahedra sharing one $\mathrm{N}^{3-}$, can provide intriguing voltage as cathodes. The divalent nitridophosphate analogue was firstly investigated as cathode for lithium ion batteries, with the $\mathrm{Fe}^{2+} / \mathrm{Fe}^{3+}$ redox couple [21]. Due to the strong inductive effect of $\mathrm{PO}_{3} \mathrm{~N}$ groups, $\mathrm{Li}_{2} \mathrm{Fe}_{2}\left(\mathrm{PO}_{3}\right)_{3} \mathrm{~N}$ delivers a high potential, as high as $3.5 \mathrm{~V}\left(\mathrm{vs}\right.$. $\mathrm{Li}^{+} / \mathrm{Li}$ ), which is $0.1 \mathrm{~V}$ higher than the olivine $\mathrm{LiFePO}_{4}$, and a high theoretical capacity of $142 \mathrm{mAh} \mathrm{g}^{-1}$, demonstrating the possibility to design high potential cathode materials for Li-ion batteries. On the Na-ion battery side, cubic $\mathrm{Na}_{3} \mathrm{Ti}\left(\mathrm{PO}_{3}\right)_{3} \mathrm{~N}$ exhibits good reversibility for sodium ion (de-)insertion with extremely small volume changes during the sodiation and desodiation process [22]. However, this material only exhibits an average working potential of $2.7 \mathrm{~V}$ vs. $\mathrm{Na}^{+} / \mathrm{Na}$ originating from the $\mathrm{Ti}^{3+} / \mathrm{Ti}^{4+}$ redox couple, and a theoretical capacity of $74 \mathrm{mAh} \mathrm{g}^{-1}$. To maximize the energy density of this kind of materials, the most significant improvement lies in the flexibility of increasing the open-circuit voltage by manipulation of the $3 \mathrm{~d}-$ metal $\mathrm{Mn}^{+} / \mathrm{M}^{(\mathrm{n}+1)+}$ redox couple in the polyanionic framework.

Herein, we report for the first time, the electrochemical properties of cubic $\mathrm{Na}_{3} \mathrm{~V}\left(\mathrm{PO}_{3}\right)_{3} \mathrm{~N}$ as cathodes for NIBs, with $\mathrm{V}^{3+/ 4+}$ redox activities. The nitridophosphate was synthesized by conventional solid state method. As a cathode in non-aqueous NIBs, this material exhibits an average operating potential around $4.0 \mathrm{~V}$ vs. $\mathrm{Na}^{+} / \mathrm{Na}$, while $0.74 \mathrm{Na}^{+}$can be extracted from the host structure.

\section{Materials and Methods}

\subsection{Mateirals Synthesis}

The $\mathrm{Na}_{3} \mathrm{~V}\left(\mathrm{PO}_{3}\right)_{3} \mathrm{~N}$ powder was synthesized via a conventional one-step solid state method. Typically, sodium polyphosphate $\left(\left(\mathrm{NaPO}_{3}\right)_{\mathrm{n}}\right.$, pure, Acros Organics, Morris Plains, NJ, USA) and vanadium oxide $\left(\mathrm{V}_{2} \mathrm{O}_{5}, \geq 99.6 \%\right.$, 10 mesh, Alfa Aesar, Karlsruhe, Germany) in a molar ratio of 6:1 were manually ground with mortar and pestle at ambient temperature for $30 \mathrm{~min}$. Then the yellow powders were placed in an alumina crucible with excessive melamine ( 5 molar equivalents, $\mathrm{C}_{3} \mathrm{H}_{6} \mathrm{~N}_{6}$, Sigma Aldrich, $\geq 99 \%$, St. Louis, MO, USA) as nitrogen sources, followed by a pre-heating treatment at $200{ }^{\circ} \mathrm{C}$ for $3 \mathrm{~h}$ and final calcination at $700{ }^{\circ} \mathrm{C}$ for $10 \mathrm{~h}$ under extremely slow Ar flow (heating rate: $\left.5^{\circ} \mathrm{C} \min ^{-1}\right)$.

\subsection{Structural Characterization}

X-ray diffraction analysis was performed in Bragg-Brentano geometry using a Bruker D8 Advance diffractometer (Bruker, Karlsruhe, Germany). All diffractograms were recorded with $\mathrm{CuK} \alpha$ radiation $(\lambda=0.154 \mathrm{~nm})$ in the $2 \theta$ range of $10-90^{\circ}$ with a step size of $0.01^{\circ}$ and a time per step of $0.5 \mathrm{~s}$. The structures were refined using the Rietveld method with the DIFFRAC PLUS TOPAS 4.2 software (Bruker, Germany). Morphological characterization was conducted on ZEISS 1550VP Field Emission SEM (Carl Zeiss, Jena, Germany). Thermal stability was determined by a thermogravimetric analyzer (TGA-209F, Netzsch, Selb, Germany) from RT to $800{ }^{\circ} \mathrm{C}$ (heating rate $=5{ }^{\circ} \mathrm{C} \mathrm{min}^{-1}$ ) under steady $\mathrm{N}_{2}$ and $\mathrm{O}_{2}$ flows $\left(20 \mathrm{~mL} \mathrm{~min}^{-1}\right)$, respectively. In situ XRD analyses, coupled with galvanostatic sodiation and desodiation, were performed. 


\subsection{Electrochemical Characterization}

The electrochemical tests were performed using three electrode Swagelok-type cells assembled in an argon-filled glove box. Sodium half-cells were assembled by using glass fiber (Whatman) as separator, sodium metal (99.8\%, Acros Organics) as counter and reference electrodes, and $1 \mathrm{M} \mathrm{NaPF} 6$ (99\%, Alfa Aesar) in propylene carbonate (PC) with $2 \mathrm{wt} . \%$ fluoroethylene carbonate (FEC) (Battery Grade, BASF, Ludwigshafen, Germany) as electrolyte. The working electrodes were prepared by doctor-blade casting a slurry of $80 \mathrm{wt} . \%$ of active material, $10 \mathrm{wt}$ \% of carbon black (Super C65, IMERYS, Bodio, Switzerland) and $10 \mathrm{wt} . \%$ of polyvinylidenefluoride (6020 Solef, Arkema Group, Paris, France) in N-methyl-2-pyrrolidone (anhydrous, Sigma-Aldrich, St Louis, MO, USA) on Al foil as current collector. After drying, electrodes with a diameter of $12 \mathrm{~mm}$ were punched, pressed, and dried at $120^{\circ} \mathrm{C}$ in vacuum. The mass loading of the electrodes is $\sim 3.5 \mathrm{mg} \mathrm{cm}^{-2}$. A Maccor 4000 Battery system (Maccor, Tulsa, OK, USA) was used for the galvanostatic charge/discharge test at $10 \mathrm{~mA} \mathrm{~g}^{-1}$ and $20 \mathrm{~mA} \mathrm{~g}^{-1}$. Cyclic voltammetry was performed on a multichannel potentiostat/galvanostat (VMP3, Biologic Science Instruments, Claix, France). All measurements were performed in climatic chambers at a temperature of $20 \pm 1{ }^{\circ} \mathrm{C}$.

\section{Results and Discussion}

Pristine $\mathrm{Na}_{3} \mathrm{~V}\left(\mathrm{PO}_{3}\right)_{3} \mathrm{~N}$ powders were synthesized by conventional sold state method, but different from other reports on the nitridophosphate analogues synthesis, without flowing ammonia gas [21-23]. The crystal structure of $\mathrm{Na}_{3} \mathrm{~V}\left(\mathrm{PO}_{3}\right)_{3} \mathrm{~N}$ was determined by X-ray diffraction (XRD, Figure 1), including Rietveld refinement of the obtained XRD pattern. The results of the refinement confirm, that $\mathrm{Na}_{3} \mathrm{~V}\left(\mathrm{PO}_{3}\right)_{3} \mathrm{~N}$ adopts a cubic structure $\left(\mathrm{a}=9.440\right.$ (1) $\AA$ ) with a space group of $P 2{ }_{1} 3$ and, thus, is isostructural to $\mathrm{Na}_{3} \mathrm{Ti}\left(\mathrm{PO}_{3}\right)_{3} \mathrm{~N}$ (ICSD: 172056) [22]. The refinement shows satisfactory agreement factors (Rwp (weighted-profile R-factor) $=8.7 \%$, GOF (goodness of fit) $=1.41$ ). The diffractogram in Figure 1 does not depict crystalline impurity phases, suggesting that the simplified synthesis method herein used is successful to obtain pure cubic $\mathrm{Na}_{3} \mathrm{M}\left(\mathrm{PO}_{3}\right)_{3} \mathrm{~N}$ phase. The refined cell parameters and atomic occupancy values are summarized in Supplementary Materials Tables S1 and S2, respectively. The SEM image (inset in Figure 1) shows that the synthesized powder is composed of irregular-shaped microscale particles. The refined crystal structure and the connectivity of trimers of $\mathrm{PO}_{3} \mathrm{~N}$ tetrahedra with the local environments of $\mathrm{Na}$ and $\mathrm{V}$ atoms are shown in Figure 2. The structure of this compound is composed of $\mathrm{VO}_{6}$ octahedra and $\mathrm{PO}_{3} \mathrm{~N}$ tetrahedra. Three $\mathrm{PO}_{3} \mathrm{~N}$ tetrahedra build up a nitridotriphosphate group, $\left(\mathrm{PO}_{3}\right)_{3} \mathrm{~N}$ sharing a common $\mathrm{N}^{3-}$-anion. As shown in Figure $2 \mathrm{~b}$, $\mathrm{Na}^{+}$ions occupy three distinct sites. One $\mathrm{Na}^{+}$ion is coordinated by six $\mathrm{O}$ atoms and one $\mathrm{N}$ atom (Na1), while the other two $\mathrm{Na}^{+}$cations are surrounded by six (Na2) and nine $\mathrm{O}$ anions (Na3: six more long-distanced $\mathrm{O}$ atoms are not shown in the structure), respectively [24]. Based on the calculation results on the $\mathrm{Na}{ }_{3} \mathrm{Ti}\left(\mathrm{PO}_{3}\right)_{3} \mathrm{~N}$ system, $\mathrm{Na} 1$ and $\mathrm{Na} 3$ sites show high mobility for Na migration, while $\mathrm{Na} 2$ site is inaccessible due to the high energy barrier. This cubic structure, bridged by trimers of $\mathrm{PO}_{3} \mathrm{~N}$ tetrahedra, offers a three-dimensional framework for Na-ion migration and contributes to the structural stability [24]. 


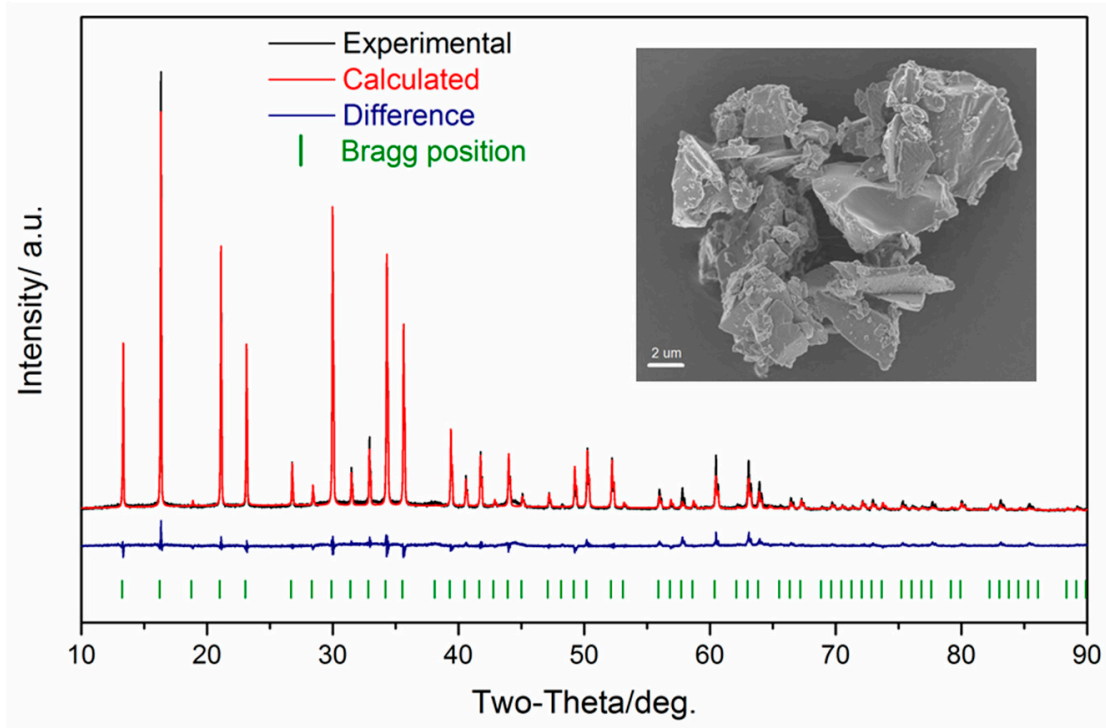

Figure 1. Rietveld refinement and powder $\mathrm{X}$-ray diffraction (XRD) pattern for $\mathrm{Na}_{3} \mathrm{~V}\left(\mathrm{PO}_{3}\right)_{3} \mathrm{~N}$ powders. The inset figure displays the SEM images.

(a) $\stackrel{b}{a}$

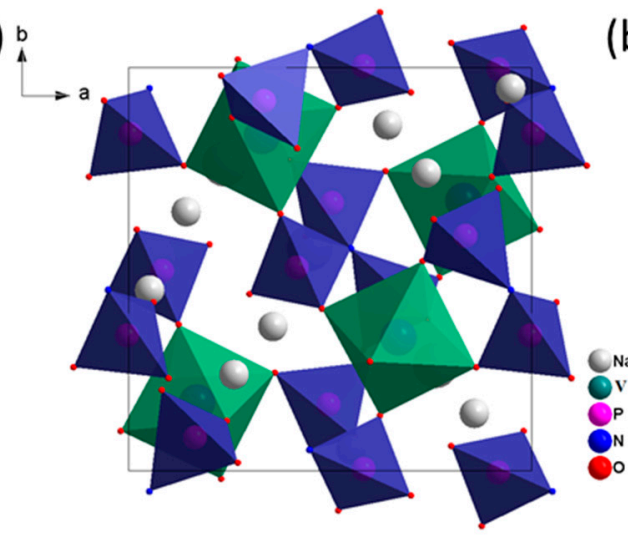

(b)

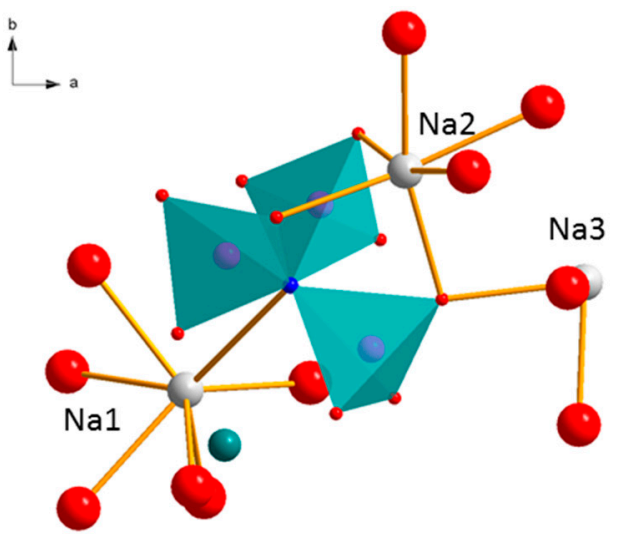

Figure 2. (a) Refined crystal structure of $\mathrm{Na}_{3} \mathrm{~V}\left(\mathrm{PO}_{3}\right)_{3} \mathrm{~N}$ and (b) the connectivity of trimers of $\mathrm{PO}_{3} \mathrm{~N}$ tetrahedra with the local environments of $\mathrm{Na}, \mathrm{V}$ atoms.

Thermal gravimetric analysis (TGA) was used to assess the thermal stability of the material under both inert $\left(\mathrm{N}_{2}\right)$ and oxygen $\left(\mathrm{O}_{2}\right)$ atmospheres. The TGA curves in the temperature range of RT- $800{ }^{\circ} \mathrm{C}$ are displayed in Figure S1 (see Supplementary Materials). It should be noted that there is no weight decrease under $\mathrm{N}_{2}$ flow up to $800^{\circ} \mathrm{C}$, indicating the superior thermal stability of the material. However, when exposed to $\mathrm{O}_{2}$, a weight increase starting from $400{ }^{\circ} \mathrm{C}$ is observed, resulting from the oxidation of $\mathrm{V}^{3+}$ to $\mathrm{V}^{5+}$ and $\mathrm{V}^{4+}$, which was also observed in $\mathrm{Na}_{3} \mathrm{~V}_{2}\left(\mathrm{PO}_{4}\right)_{3}$ system [25]. Apart from this oxidization process, it should be highlighted that no thermal decomposition is evident during heating, illustrating the excellent thermal stability, which is why $\mathrm{Na}_{3} \mathrm{~V}\left(\mathrm{PO}_{3}\right)_{3} \mathrm{~N}$ can be regarded as safe electrode materials in batteries. It should be noted that the melamine completely decomposes between $250-350^{\circ} \mathrm{C}$ and does not introduce any additional carbon or impurities into the material, as indicated by the thermogravimetric analysis of pristine melamine in $\mathrm{N}_{2}$ atmosphere (Figure S1, Supplementary Materials).

The electrochemical performance of pristine $\mathrm{Na}_{3} \mathrm{~V}\left(\mathrm{PO}_{3}\right)_{3} \mathrm{~N}$ electrode was investigated in T-type cells with $\mathrm{Na}$-metal as counter and reference electrode. Cyclic voltammograms at various scan rates between 3.2-4.5 V vs. Na/ $\mathrm{Na}^{+}$are presented in Figure 3a. The CV sweeps reveal that the $\mathrm{Na}_{3} \mathrm{~V}\left(\mathrm{PO}_{3}\right)_{3} \mathrm{~N}$ electrode shows electrochemical activity centered at $4.0 \mathrm{~V}$ with only one pair of redox peaks associated 
to the $\mathrm{V}^{3+/ 4+}$ redox couple. Despite the slight cell polarization, the reversibility of the sodium insertion is maintained at a higher scan rate. Figure $3 b$ shows the first galvanostatic charge and discharge (GCD) curve of the cell between 3.2 and $4.5 \mathrm{~V}$ at a current of $10 \mathrm{~mA} \mathrm{~g}^{-1}$. The electrode exhibits a single plateau around $4.0 \mathrm{~V}$ in both charge and discharge. During the first charge to $4.5 \mathrm{~V}, 0.74$ eq. of $\mathrm{Na}$ (55 $\mathrm{mAh} \mathrm{g}^{-1}$ ) are extracted from the host structure. However, only half ( 0.38 eq.) of the Na ions were re-inserted, leading to a high irreversible capacity for the first cycle. The theoretical capacity for the reversible shuttling of 1.0 eq. $\mathrm{Na}^{+}$per each formula unit of $\mathrm{Na}_{3} \mathrm{~V}\left(\mathrm{PO}_{3}\right)_{3} \mathrm{~N}$ is $72 \mathrm{mAh} \mathrm{g}^{-1}$. The lower charge capacity in the first cycle, hence, indicates that not all $\mathrm{Na}^{+}$can be extracted from the host structure. Increasing the current density to $20 \mathrm{~mA} \mathrm{~g}^{-1}$, this material delivers a discharge capacity of $24 \mathrm{mAh} \mathrm{g}^{-1}$ (see Supplementary Materials Figure S2). It is worth mentioning that, although the capacity is low, the measured discharge capacities are stable over 10 cycles, suggesting that after optimization such electrodes could work with high cycling stability after the initial capacity loss. For instance, nano-sizing [26], carbon coating [27], and doping [28] are promising strategies to improve the rate capability due to shortened ion diffusion pathways and enhanced electronic and ionic conductivities, respectively.

(a)

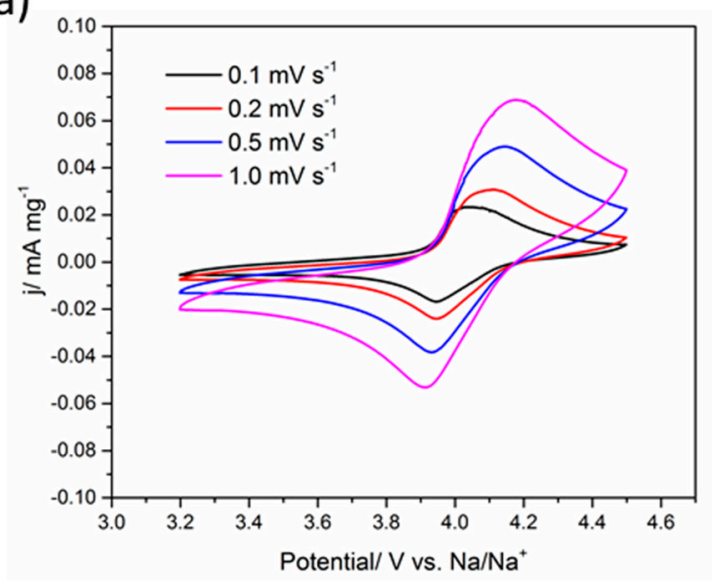

(b)

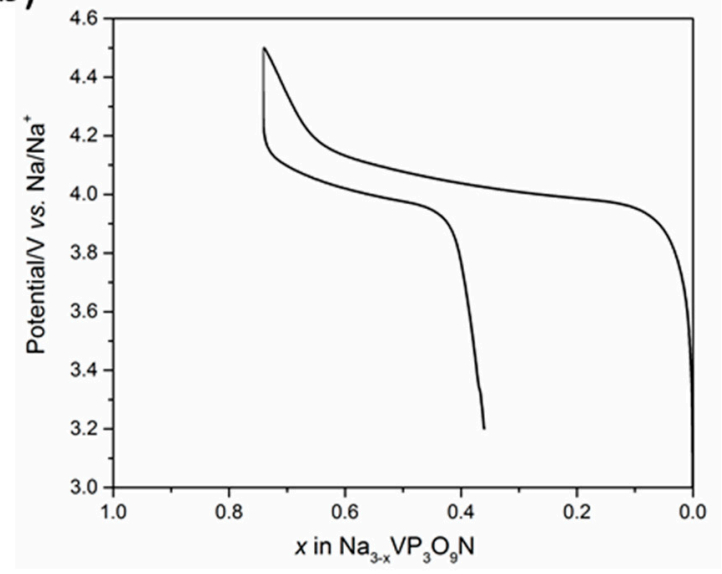

Figure 3. (a) Cyclic voltammograms in the potential range of $3.2-4.5 \mathrm{~V}$ at various scan rates and (b) first cycle galvanostatic discharge/charge profile between 3.2 and $4.5 \mathrm{~V}$ at a current of $10 \mathrm{~mA} \cdot \mathrm{g}^{-1}$ of $\mathrm{Na}_{3} \mathrm{~V}\left(\mathrm{PO}_{3}\right)_{3} \mathrm{~N}$.

The apparent $\mathrm{Na}^{+}$diffusion coefficients may be derived from the $\mathrm{CV}$ profiles at various scan rates. Indeed, if the charge transfer at the interface is fast enough, the relationship of the peak current and the CV sweep rate can be described via the simplified Randles-Sevcik Equation (1) [25,29]

$$
i_{p}=k n^{3 / 2} A D_{\mathrm{Na}^{+}}{ }^{1 / 2} C_{\mathrm{Na}^{+}} v^{1 / 2}
$$

where $i_{p}$ is the peak current (A), $k$ is a constant value of $2.69 \times 10^{5} \mathrm{C} \mathrm{mol}^{-1} \mathrm{~V}^{-1 / 2}$ under standard conditions $\left(25^{\circ} \mathrm{C}\right), n$ is the number of electrons (1), $A$ is the contact area between electrode and electrolyte $\left(1.13 \mathrm{~cm}^{2}\right)$, and $\mathrm{C}_{\mathrm{Na}^{+}}$is the concentration of sodium ions in the material $\left(2.37 \times 10^{-4} \mathrm{~mol} \mathrm{~cm}{ }^{-3}\right.$ in $\left.\mathrm{Na}_{3} \mathrm{~V}\left(\mathrm{PO}_{3}\right)_{3} \mathrm{~N}\right), v$ is the scan rate $\left(\mathrm{V} \mathrm{s}^{-1}\right)$. When plotting the peak current $i_{p}$ versus the square root of the scan rate $v$, a linear behavior is observed (see Figure S3). The apparent $\mathrm{Na}^{+}$diffusion coefficients are $1.15 \times 10^{-12} \mathrm{~cm}^{2} \mathrm{~s}^{-1}$ (cathodic) and $7.13 \times 10^{-13} \mathrm{~cm}^{2} \mathrm{~s}^{-1}$ (anodic), respectively. These values are much lower than those for $\mathrm{Na}_{3} \mathrm{Ti}\left(\mathrm{PO}_{3}\right)_{3} \mathrm{~N}$ but similar to those for $\mathrm{Na}_{3} \mathrm{~V}_{2}\left(\mathrm{PO}_{4}\right)_{3}[22,25]$.

In situ XRD measurement was conducted to understand the structural changes during the initial sodiation and desodiation processes. The XRD patterns (Figure $4 \mathrm{~b}$ ) were collected during the first cycle, each after extraction or insertion of 0.025 eq. $\mathrm{Na}^{+}$(in total: 44 diffraction patterns). The voltage profile 
resulting from the galvanostatic steps during the in situ characterization is presented in Figure 4a. From Figure $4 b$, only imperceptible changes of the intensity and position of the reflections are observed. This suggests that only small structural and volume changes occur upon (de-)sodiation and supports a stable two-phase reaction (Na-poor and Na-rich), as also indicated by the flat charge-discharge potential profiles [30]. The small intensity changes in the XRD powder patterns for the desodiated and sodiated samples (Figure S3) are consistent with the observed electrochemical reversibility of the system. To further investigate the desodiated and sodiated phases, Rietveld refinements of the XRD patterns of electrodes in fully charged $(4.5 \mathrm{~V})$ and discharged $(3.2 \mathrm{~V})$ state were performed. The according Na occupancies and lattice parameters are listed in Table 1. All diffractograms were successfully refined with the space group $P 2{ }_{1} 3$, i.e., cubic lattice parameters. The results demonstrate that $\mathrm{Na}^{+}$ions at $\mathrm{Na} 1$ and $\mathrm{Na} 3$ sites are firstly extracted when charged to $4.5 \mathrm{~V}$, resulting in a total amount of about 0.7 eq. $\mathrm{Na}^{+}$. Na cations at these two sites are, therefore, more mobile. During the discharge process, 0.3 eq. of $\mathrm{Na}^{+}$cannot be electrochemically re-inserted into the host structure, which is in agreement with the irreversible capacity in the first cycle as shown in Figure 3b. This preliminary result indicates that less capacity contribution is from $\mathrm{Na} 3$ site resulting from the higher diffusion barrier for $\mathrm{Na} 3$ than Na1, and there is almost no Na migration occurring at the Na2 site, in accordance with the previous study on $\mathrm{Na}_{3} \mathrm{Ti}\left(\mathrm{PO}_{3}\right)_{3} \mathrm{~N}$ [22]. However, the Na ion mobility at $\mathrm{Na} 1$ sites is highly reversible. This insight may provide a strategy to improve the Na-migration by tuning the structural properties via selective doping, for example. Moreover, the volume change $(\Delta \mathrm{V} / \mathrm{V})$, obtained from the calculated cell volume difference before $(\mathrm{OCV})$ and after $(4.5 \mathrm{~V})$ Na removal by Rietveld refinement, that occurs on Na-ion removal is approximately $0.2 \%$, a remarkably small volume shrinkage given the large ionic radius of $\mathrm{Na}$ ions. This is contributed by the framework constructed of $\mathrm{PO}_{3} \mathrm{~N}$ tetrahedra trimers.

(a)

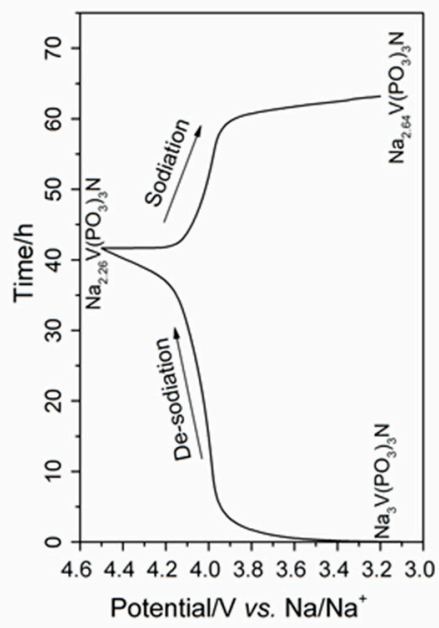

(b)

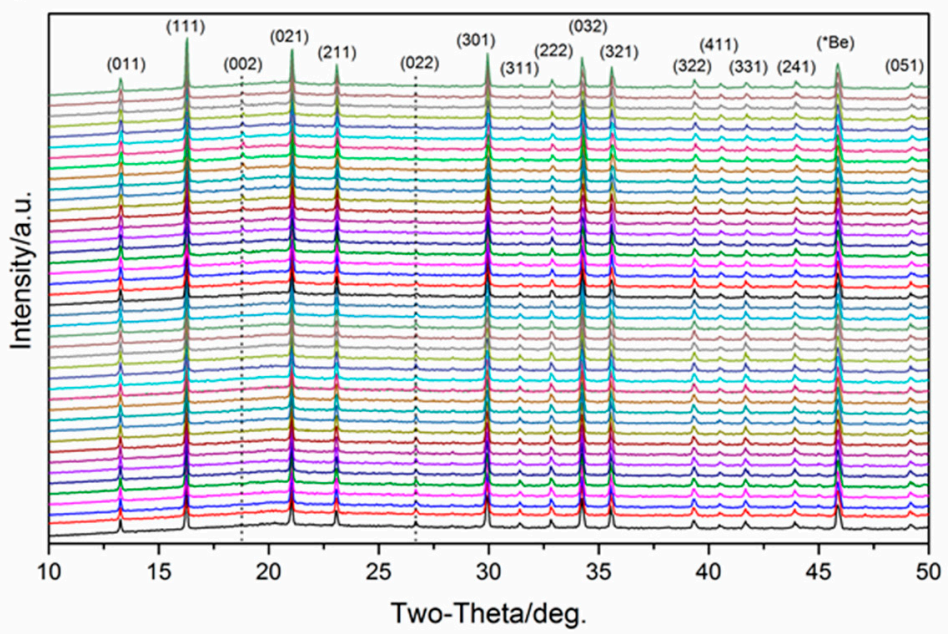

Figure 4. (a) Typical charge/discharge profile and (b) in situ X-ray diffraction patterns of $\mathrm{Na}_{3} \mathrm{~V}\left(\mathrm{PO}_{3}\right)_{3} \mathrm{~N}$ electrode during the first cycle.

Table 1. Refined Na occupancies, lattice parameter, and cell volume extracted from the Rietveld refinement of diffraction patterns from $10-45^{\circ} 2 \theta$ of $\mathrm{Na}_{3} \mathrm{~V}\left(\mathrm{PO}_{3}\right)_{3} \mathrm{~N}$ electrodes at $\mathrm{OCV}$, fully charged and fully discharged state in the first cycle.

\begin{tabular}{cccccccc}
\hline State & Na1 occ & Na2 occ & Na3 occ & $\boldsymbol{a}(\AA)$ & $\boldsymbol{V}\left(\AA^{3}\right)$ & $\mathbf{R}_{\mathbf{w p}} / \%$ & GOF \\
\hline OCV & $1.05(3)$ & $1.00(2)$ & $0.91(3)$ & $9.445(1)$ & $842.7(2)$ & 3.38 & 1.14 \\
1st charge: $4.5 \mathrm{~V}$ & $0.58(4)$ & $0.97(2)$ & $0.76(3)$ & $9.438(1)$ & $840.8(3)$ & 3.43 & 1.16 \\
1st discharge: $3.2 \mathrm{~V}$ & $0.85(3)$ & $1.01(2)$ & $0.80(3)$ & $9.440(1)$ & $841.4(2)$ & 3.27 & 1.10 \\
\hline
\end{tabular}




\section{Conclusions}

Summarizing, the nitridophosphate $\mathrm{Na}_{3} \mathrm{~V}\left(\mathrm{PO}_{3}\right)_{3} \mathrm{~N}$ with a cubic structure can be successfully synthesized via a conventional solid-state method without flowing ammonia gas as nitrogen source. This compound shows a high operating potential of $4.0 \mathrm{~V}$ vs. Na/ $\mathrm{Na}^{+}$due to $\mathrm{V}^{3+/ 4+}$ redox reactions. In the first charge, 0.74 eq. $\mathrm{Na}^{+}$can be extracted but only 0.38 eq. $\mathrm{Na}^{+}$(i.e., $28 \mathrm{mAh} \mathrm{g}^{-1}$ ) can be re-inserted into the framework and reversibly shuttled. It should be noted that the potential of $\mathrm{V}^{3+/ 4+}$ in most polyanionic cathodes is lower than $4.0 \mathrm{~V}$ vs. $\mathrm{Na} / \mathrm{Na}^{+}$. The nitridophosphate $\mathrm{Na}_{3} \mathrm{~V}\left(\mathrm{PO}_{3}\right)_{3} \mathrm{~N}$ exhibits a $\mathrm{V}^{3+/ 4+}$ redox reaction at $4.0 \mathrm{~V}$, higher than that of $\mathrm{Na}_{3} \mathrm{~V}_{2}\left(\mathrm{PO}_{4}\right)_{3}(3.4 \mathrm{~V}$ vs. $\mathrm{Na} / \mathrm{Na}^{+}$). Although this kind of compound offers a limited reversible capacity, room to improve the performance and narrow the gap between the practical and theoretical capacities is existing. The most obvious is to improve the conductivity and optimize the particle size with morphology control via, e.g., nano-sizing and carbon-coating. However, the excellent thermal stability and very small volume changes during (de)sodiation, i.e., "zero strain", with high operating voltage, make this kind of compounds a potentially interesting safe high-voltage cathode material for sodium-ion batteries.

Supplementary Materials: The following are available online at www.mdpi.com/1996-1073/10/7/889/s1, Table S1: Crystallographic data of $\mathrm{Na}_{3} \mathrm{~V}\left(\mathrm{PO}_{3}\right)_{3} \mathrm{~N}$, Table S2: Atomic parameters for $\mathrm{Na}_{3} \mathrm{~V}\left(\mathrm{PO}_{3}\right)_{3} \mathrm{~N}$, Figure S1: TG curves of $\mathrm{Na}_{3} \mathrm{~V}\left(\mathrm{PO}_{3}\right)_{3} \mathrm{~N}$ and melamine under $\mathrm{N}_{2}$ and $\mathrm{O}_{2}$ flows of $20 \mathrm{~mL} \mathrm{~min}^{-1}$ within the temperature range of $30-800{ }^{\circ} \mathrm{C}$ at $5{ }^{\circ} \mathrm{C} \mathrm{min}-1$ heating rate, Figure S2: Galvanostatic charge-discharge profiles of $\mathrm{Na}_{3} \mathrm{~V}\left(\mathrm{PO}_{3}\right)_{3} \mathrm{~N}$ at current density of $10 \mathrm{~mA} \mathrm{~g}^{-1}$ and $20 \mathrm{~mA} \mathrm{~g}^{-1}$ for the 1st and 10th cycles, Figure S3: Peak current $\left(\mathrm{I}_{\mathrm{p}}, \mathrm{A} \mathrm{cm}^{-2}\right)$ vs. square root of scan rate $\left(\mathrm{v}^{1 / 2}, \mathrm{~V}^{1 / 2} \mathrm{~s}^{-1 / 2}\right)$ and related linear fit corresponding to the $\mathrm{V}^{3+/ 4+}$ redox processes, Figure S4: In situ X-ray diffraction patterns of $\mathrm{Na}_{3} \mathrm{~V}\left(\mathrm{PO}_{3}\right)_{3} \mathrm{~N}$ at $\mathrm{OCV}$, after the 1st charge $(4.5 \mathrm{~V})$ and 1st discharge state $(3.2 \mathrm{~V})$.

Acknowledgments: The author, Huang Zhang, gratefully acknowledges the financial support from Chinese State Scholarship Fund. The financial support of Helmholtz Association is also acknowledged.

Author Contributions: Huang Zhang designed and performed the experiments; Huang Zhang wrote the original manuscript; Daniel Buchholz and Stefano Passerini revised the paper and supervised the work. All authors read and approved the final manuscript.

Conflicts of Interest: The authors declare no conflict of interest.

\section{References}

1. Tarascon, J.M.; Armand, M. Issues and challenges facing rechargeable lithium batteries. Nature 2001, 414, 359-367. [CrossRef] [PubMed]

2. Choi, J.W.; Aurbach, D. Promise and reality of post-lithium-ion batteries with high energy densities. Nat. Rev. Mater. 2016, 1, 16013. [CrossRef]

3. Slater, M.D.; Kim, D.; Lee, E.; Johnson, C.S. Sodium-ion batteries. Adv. Funct. Mater. 2013, 23, 947-958. [CrossRef]

4. Yabuuchi, N.; Kubota, K.; Dahbi, M.; Komaba, S. Research development on sodium-ion batteries. Chem. Rev. 2014, 114, 11636-11682. [CrossRef] [PubMed]

5. Ong, S.P.; Chevrier, V.L.; Hautier, G.; Jain, A.; Moore, C.; Kim, S.; Ma, X.; Ceder, G. Voltage, stability and diffusion barrier differences between sodium-ion and lithium-ion intercalation materials. Energy Environ. Sci. 2011, 4, 3680-3688. [CrossRef]

6. Palomares, V.; Serras, P.; Villaluenga, I.; Hueso, K.B.; Carretero-Gonzalez, J.; Rojo, T. Na-ion batteries, recent advances and present challenges to become low cost energy storage systems. Energy Environ. Sci. 2012, 5, 5884-5901. [CrossRef]

7. Lee, K.T.; Ramesh, T.N.; Nan, F.; Botton, G.; Nazar, L.F. Topochemical synthesis of sodium metal phosphate olivines for sodium-ion batteries. Chem. Mater. 2011, 23, 3593-3600. [CrossRef]

8. Saravanan, K.; Mason, C.W.; Rudola, A.; Wong, K.H.; Balaya, P. The first report on excellent cycling stability and superior rate capability of $\mathrm{Na}_{3} \mathrm{~V}_{2}\left(\mathrm{PO}_{4}\right)_{3}$ for sodium ion batteries. Adv. Energy Mater. 2013, 3, 444-450. [CrossRef] 
9. Kim, H.; Shakoor, R.A.; Park, C.; Lim, S.Y.; Kim, J.-S.; Jo, Y.N.; Cho, W.; Miyasaka, K.; Kahraman, R.; Jung, Y.; et al. $\mathrm{Na}_{2} \mathrm{FeP}_{2} \mathrm{O}_{7}$ as a promising iron-based pyrophosphate cathode for sodium rechargeable batteries: A combined experimental and theoretical study. Adv. Funct. Mater. 2013, 23, 1147-1155. [CrossRef]

10. Ellis, B.L.; Makahnouk, W.R.M.; Rowan-Weetaluktuk, W.N.; Ryan, D.H.; Nazar, L.F. Crystal structure and electrochemical properties of $\mathrm{A}_{2} \mathrm{MPO}_{4} \mathrm{~F}$ fluorophosphates $(\mathrm{A}=\mathrm{Na}, \mathrm{Li} ; \mathrm{M}=\mathrm{Fe}, \mathrm{Mn}, \mathrm{Co}, \mathrm{Ni})$. Chem. Mater. 2010, 22, 1059-1070. [CrossRef]

11. Chihara, K.; Kitajou, A.; Gocheva, I.D.; Okada, S.; Yamaki, J.-I. Cathode properties of $\mathrm{Na}_{3} \mathrm{M}_{2}\left(\mathrm{PO}_{4}\right)_{2} \mathrm{~F}_{3}$ [M = Ti, Fe, V] for sodium-ion batteries. J. Power Sources 2013, 227, 80-85. [CrossRef]

12. Singh, P.; Shiva, K.; Celio, H.; Goodenough, J.B. Eldfellite $\mathrm{NaFe}\left(\mathrm{SO}_{4}\right)_{2}$ : An intercalation cathode host for low-cost Na-ion batteries. Energy Environ. Sci. 2015, 8, 3000-3005. [CrossRef]

13. Barpanda, P.; Chotard, J.-N.; Recham, N.; Delacourt, C.; Ati, M.; Dupont, L.; Armand, M.; Tarascon, J.-M.

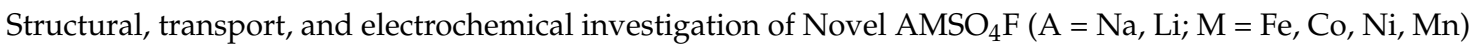
metal fluorosulphates prepared using low temperature synthesis routes. Inorg. Chem. 2010, 49, 7401-7413. [CrossRef] [PubMed]

14. Li, S.; Guo, J.; Ye, Z.; Zhao, X.; Wu, S.; Mi, J.-X.; Wang, C.-Z.; Gong, Z.; McDonald, M.J.; Zhu, Z.; et al. A zero-strain $\mathrm{Na}_{2} \mathrm{FeSiO}_{4}$ as novel cathode material for sodium ion batteries. ACS Appl. Mater. Interfaces 2016, 8, 17233-17238. [CrossRef] [PubMed]

15. Wood, S.M.; Eames, C.; Kendrick, E.; Islam, M.S. Sodium ion diffusion and voltage trends in phosphates $\mathrm{Na}_{4} \mathrm{M}_{3}\left(\mathrm{PO}_{4}\right)_{2} \mathrm{P}_{2} \mathrm{O}_{7}(\mathrm{M}=\mathrm{Fe}, \mathrm{Mn}, \mathrm{Co}, \mathrm{Ni})$ for possible high-rate cathodes. J. Phys. Chem. C 2015, 119, 15935-15941. [CrossRef]

16. Zhang, H.; Hasa, I.; Buchholz, D.; Qin, B.; Geiger, D.; Jeong, S.; Kaiser, U.; Passerini, S. Exploring the Ni redox activity in polyanionic compounds as conceivable high potential cathodes for Na rechargeable batteries. NPG Asia Mater. 2017, 9, e370. [CrossRef]

17. Barpanda, P.; Ati, M.; Melot, B.C.; Rousse, G.; Chotard, J.N.; Doublet, M.L.; Sougrati, M.T.; Corr, S.A.; Jumas, J.C.; Tarascon, J.M. A 3.90 V iron-based fluorosulphate material for lithium-ion batteries crystallizing in the triplite structure. Nat. Mater. 2011, 10, 772-779. [CrossRef] [PubMed]

18. Zatovsky, I. NASICON-type $\mathrm{Na}_{3} \mathrm{~V}_{2}\left(\mathrm{PO}_{4}\right)_{3}$. Acta Crystallogr. Sect. E 2010, 66, i12. [CrossRef] [PubMed]

19. Gover, R.K.B.; Bryan, A.; Burns, P.; Barker, J. The electrochemical insertion properties of sodium vanadium fluorophosphate, $\mathrm{Na}_{3} \mathrm{~V}_{2}\left(\mathrm{PO}_{4}\right)_{2} \mathrm{~F}_{3}$. Solid State Ion. 2006, 177, 1495-1500. [CrossRef]

20. Liu, Z.; Hu, Y.-Y.; Dunstan, M.T.; Huo, H.; Hao, X.; Zou, H.; Zhong, G.; Yang, Y.; Grey, C.P. Local structure and dynamics in the $\mathrm{Na}$ ion battery positive electrode material $\mathrm{Na}_{3} \mathrm{~V}_{2}\left(\mathrm{PO}_{4}\right)_{2} \mathrm{~F}_{3}$. Chem. Mater. 2014, 26, 2513-2521. [CrossRef]

21. Liu, J.; Yu, X.; Hu, E.; Nam, K.-W.; Yang, X.-Q.; Khalifah, P.G. Divalent iron nitridophosphates: A new class of cathode materials for Li-ion batteries. Chem. Mater. 2013, 25, 3929-3931. [CrossRef]

22. Liu, J.; Chang, D.; Whitfield, P.; Janssen, Y.; Yu, X.; Zhou, Y.; Bai, J.; Ko, J.; Nam, K.-W.; Wu, L.; et al. Ionic conduction in cubic $\mathrm{Na}_{3} \mathrm{TiP}_{3} \mathrm{O}_{9} \mathrm{~N}$, a secondary Na-ion battery cathode with extremely low volume change. Chem. Mater. 2014, 26, 3295-3305. [CrossRef]

23. Massiot, D.; Conanec, R.; Feldmann, W.; Marchand, R.; Laurent, Y. NMR characterization of the $\mathrm{Na}_{3} \mathrm{AlP}_{3} \mathrm{O}_{9} \mathrm{~N}$ and $\mathrm{Na}_{2} \mathrm{Mg}_{2} \mathrm{P}_{3} \mathrm{O}_{9} \mathrm{~N}$ nitridophosphates: Location of the (NaAl)/ $\mathrm{Mg}_{2}$ substitution. Inorg. Chem. 1996, 35, 4957-4960. [CrossRef] [PubMed]

24. Kim, M.; Kim, S.-J. Synchrotron powder study of $\mathrm{Na}_{3} \mathrm{~V}\left(\mathrm{PO}_{3}\right)_{3} \mathrm{~N}$. Acta Crystallogr. Sect. E 2013, 69, i34. [CrossRef] [PubMed]

25. Zhang, H.; Hasa, I.; Qin, B.; Diemant, T.; Buchholz, D.; Behm, J.; Passerini, S. Excellent cycling stability and superior rate capability of $\mathrm{Na}_{3} \mathrm{~V}_{2}\left(\mathrm{PO}_{4}\right)_{3}$ cathodes enabled by nitrogen-doped carbon interpenetration for sodium-ion batteries. ChemElectroChem 2017, 4, 1256-1263. [CrossRef]

26. Wang, Y.; Cao, G. Developments in nanostructured cathode materials for high-performance lithium-ion batteries. Adv. Mater. 2008, 20, 2251-2269. [CrossRef]

27. Gaberscek, M.; Dominko, R.; Jamnik, J. Is small particle size more important than carbon coating? An example study on $\mathrm{LiFePO}_{4}$ cathodes. Electrochem. Commun. 2007, 9, 2778-2783. [CrossRef]

28. Wagemaker, M.; Ellis, B.L.; Lützenkirchen-Hecht, D.; Mulder, F.M.; Nazar, L.F. Proof of supervalent doping in olivine $\mathrm{LiFePO}_{4}$. Chem. Mater. 2008, 20, 6313-6315. [CrossRef] 
29. Hung, T.-F.; Cheng, W.-J.; Chang, W.-S.; Yang, C.-C.; Shen, C.-C.; Kuo, Y.-L. Ascorbic acid-assisted synthesis of mesoporous sodium vanadium phosphate nanoparticles with highly sp2-coordinated carbon coatings as efficient cathode materials for rechargeable sodium-ion batteries. Chem. Eur. J. 2016, 22, 10620-10626. [CrossRef] [PubMed]

30. Recham, N.; Chotard, J.N.; Dupont, L.; Delacourt, C.; Walker, W.; Armand, M.; Tarascon, J.M. A 3.6 V lithium-based fluorosulphate insertion positive electrode for lithium-ion batteries. Nat. Mater. 2010, 9, 68-74. [CrossRef] [PubMed] article distributed under the terms and conditions of the Creative Commons Attribution (CC BY) license (http://creativecommons.org/licenses/by/4.0/). 